\title{
HIGH PERFORMANCE FLEXIBLE NANOPARTICLES BASED ORGANIC ELECTRONICS
}

\author{
Dr. D. Nirmal, \\ Associate Professor, \\ Department of Electrical sciences, \\ Karunya University, \\ Karunya Nagar, Coimbatore, \\ Tamil Nadu, India - 641114. \\ Email id: nirmal@karunya.edu
}

\begin{abstract}
The attributes of the organic materials have made them more prominent in a wide range of applications engaged for large or small purpose such as the solar cells or the displays in the mobile devices. The solar cells developed using the organic semiconductors are more advantageous due to their flexibility and their easy installation. Despite the versatile nature of the and easy implementation the organic semiconductors still suffers from low efficiency in term of cost, performance and size. The proposed method incorporates the nanomaterials in the organic solar cell to improvise efficiency (performance) and to minimize the cost as well as the size of the solar cells. The proposed method replaces the semiconductor that is organic by incorporating the organic semiconductors with the nanoparticle additives to have a perfect blending in solution to improve the crystallizations of the semiconductor, and the uniformity thus improvising the power conversion efficiency in the solar cells and minimizing the size and the cost. The result acquired through evaluation proves the performance improvements to $19 \%$ form $3.5 \%$ in the solar cells.
\end{abstract}

Keywords: Nanoparticles, Organic Semiconductors, Solar Cells, Carbon Black Nanoparticle, Titanium Dioxide, Enhanced Performance

\section{INTRODUCTION}

The world we are receding in completely depends on the electronic technology to for its economic status, national security and health, to reduce the negative impacts and improvise the positive impacts over the environment the manufactures have reduced the usage of the in organic materials and started using the organic materials in the building of the electronic components. The organic electronic devices are more ecofriendly as well as affordable in the progressing world of electronics The modern organic electronics that are in use in the present day is the smart phone with the OLED (organic light emitting diode) displays, the organic materials promise many electronic technologies that are innovative and accessible. The chemical scientists are working on different varieties of organic materials such as small molecules, polymers; graphene, other molecular structure and hybrid materials in their research work on electronics. The small molecules and the polymers are used in the televisions, mobile phones, transistor and solar cells etc.

The organic materials used in the displays of the mobile phones and TV's, in solar cells in form of photovoltaic improving the solar light observation and their mobility's and in transistors enhances the mobility of the charged carriers from 0.01 centimeter squared per volt - second to 1.0 -3.0 centimeter squared per volt - second, employing a high performance polymers would further improve the mobility to 5.0-10 centimeter squared per volt -second. The figure. 1 shows the improvement in the organic electronics. 
Journal of Electronics and Informatics (2019)

Vol.01/ No. 02

Pages: 99-106

http://www.irojournals.com/iroei/

DOI: https://doi.org/10.36548/jei.2019.2.005

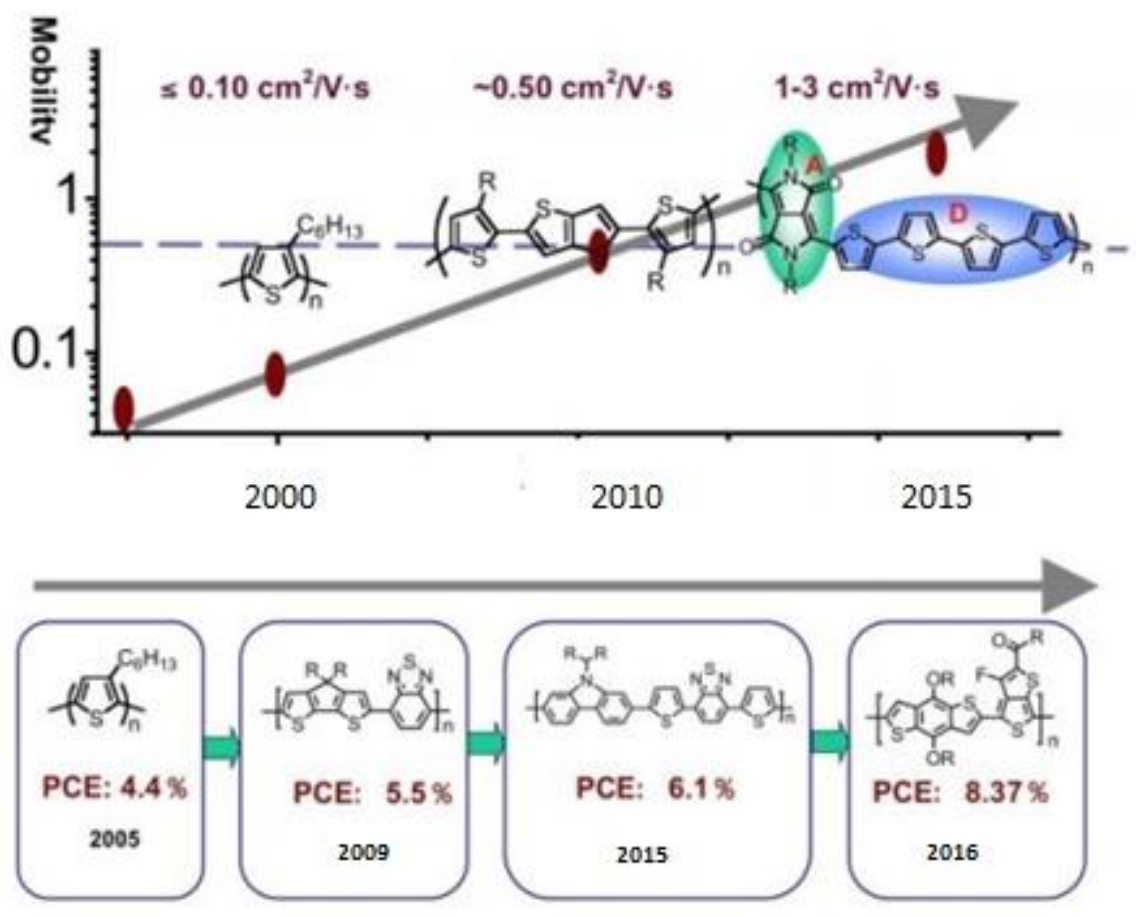

Fig.1 Improvements in the Organic Electronics

But as still the organic electronics are in infant stage, it faces challenges and efficiency problems in the realization. In the case of solar cells the organic electronics though the polymer based solar cells improves the light absorption it experiences very low power conversion efficiency, due to the improper blending process and the un-uniformity in printing. So the proposed method in the paper includes the nanoparticle additives to polymer based organic electronics to make them potentially efficient, inexpensive and solution processable enhancing the uniformity thus increasing the power conversion efficiency.

\subsection{WORKING OF ORGANIC SOLAR CELLS}

Organic solar cells similar to the mono crystalline and the poly crystalline solar cells produce electricity using the sunlight. The photo voltaic cells that present inside the solar cells convert the sunlight into electricity that is usable. The procedure to convert the light to electricity starts with the absorption of light, and knocking the electron loose from the semiconductor material, the loose electrons move and creates an electric current, The current produced is observed and sent through the wires. Unlike mono crystalline and the poly crystalline solar cells, the organic solar cells uses the carbon based semiconducting materials instead of the silicon. The figure. 2 depicts the structure of the organic cell. 
Journal of Electronics and Informatics (2019)

Vol.01/ No. 02

Pages: 99-106

http://www.irojournals.com/iroei/

DOI: https://doi.org/10.36548/jei.2019.2.005

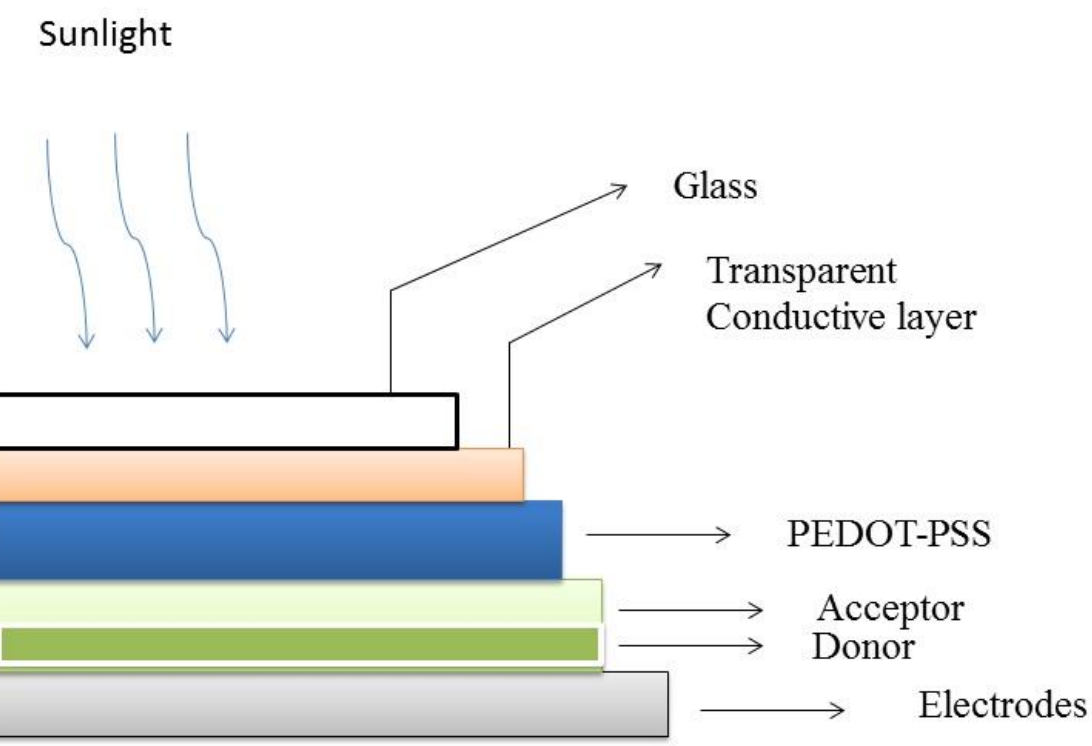

Figure.2 Organic Solar Cell Structure

The solar cells formed using the carbon based semiconducting material is fabricated and printed in form of thin plastic sheets and is used. The un-uniformity in the printing to the improper blending in the solution, to improve the blending process and print sheets with the uniformity, unlike conventional organic solar cells the proposed solar cells utilizes the nano particle additives along with the organic semiconductor for perfect blending in solution to improve the crystallizations of the semiconductor, and the uniformity in printing consequently improvising the power conversion efficiency in the solar cells and minimizing the size and the cost

The high performance flexible nanoparticles for the organic electronics presents the related work detailing the advantages of the organic electronics compared to the inorganic electronics in 2, section 3 presents the proposed work, 4 details the result observed and the section 5. Presents the conclusion of the paper, followed by the references.

\section{RELATED WORKS}

Forrest, Stephen R., et al [1] in his paper gives the "introduction on the organic electronics and the optoelectronics", Kelley et al [2] discuss the "recent progress in the organic electronics: Materials, devices, and processes" the author Palanivelu, K., Ji-Sun Im et al [3] in his paper elaborates the "Carbon doping of TiO 2 for visible light photo catalysisa review."

Zhao, Xingang et al [4] presets the "Electron transporting semiconducting polymers in organic electronics." Shaw, Jane $\mathrm{M}$ et al [5] details the "basic of the organic electronics" Perepichka et al [6] provides the "the applications of the Applications in Organic Electronics and Photonics," the author Meyer, Jens et al [7] and Zhan, Xiaowei, et al [8] provides the details of the advance materials available for the organic electronics. Chen, Wangqiao et al [9] proposes the "small molecule acceptors in organic solar cells (OSCs)." Na, Seok-In, et al [10] initiates the method to develop a low cost power generation. 
Journal of Electronics and Informatics (2019)

Vol.01/ No. 02

Pages: 99-106

http://www.irojournals.com/iroei/

DOI: https://doi.org/10.36548/jei.2019.2.005

The references [11-14] discuss the arrangement of the conventional solar cells. Nirmal, D et al [15] puts forth the analysis and the designing of the nano-carbon interconnects Bahn, Hyokyung et al [16] proposes the steps in the effectively managing he nano storage devices. Kumar, N. Mohan et al [17] presets the "energy and power efficient system on chip with Nano sheet FET."

\section{PROPOSED ORGANIC SOLAR CELL WITH NANO PARTICLE ADDITIVES}

The conventional organic solar cells (OSC) has five layers as shown in the figure. 2 the substrate, the anode, that must be transparent conductor such as the indium tin oxide. Interlayer developed with the conducting polymer PDOT: PSS that increases its work function and the active layer that includes the $\mathrm{p}$ and the $\mathrm{n}$ type semiconductors and this layer the photon gets converted into electric current. The OSC has numerous of benefits compared to the silicon based solar cells- as it is versatile, flexible and translucent, but have a very low efficiency and life expectancy

This is due to the basic properties of the semiconducting materials used, the unordered arrangement in the active layer of the OPVC especially during the liquidation period where the materials are converted in form of inks for printing affects the mobility of the electrons and holes affecting the conversion efficiency of the OSC. So the proposed design introduces the nanoparticle additives (carbon black and titanium dioxide) to the organic semiconducting material to improve the blending properties and increase the mobility thereby increasing the PCE,

\subsection{METHODOLGY}

The carbon black nanoparticle is a conductive, non-polluting power produced using the high temperature carbonization of 1330 degree Celsius, the table below provides the appearance of the carbon black along with its theoretical data.

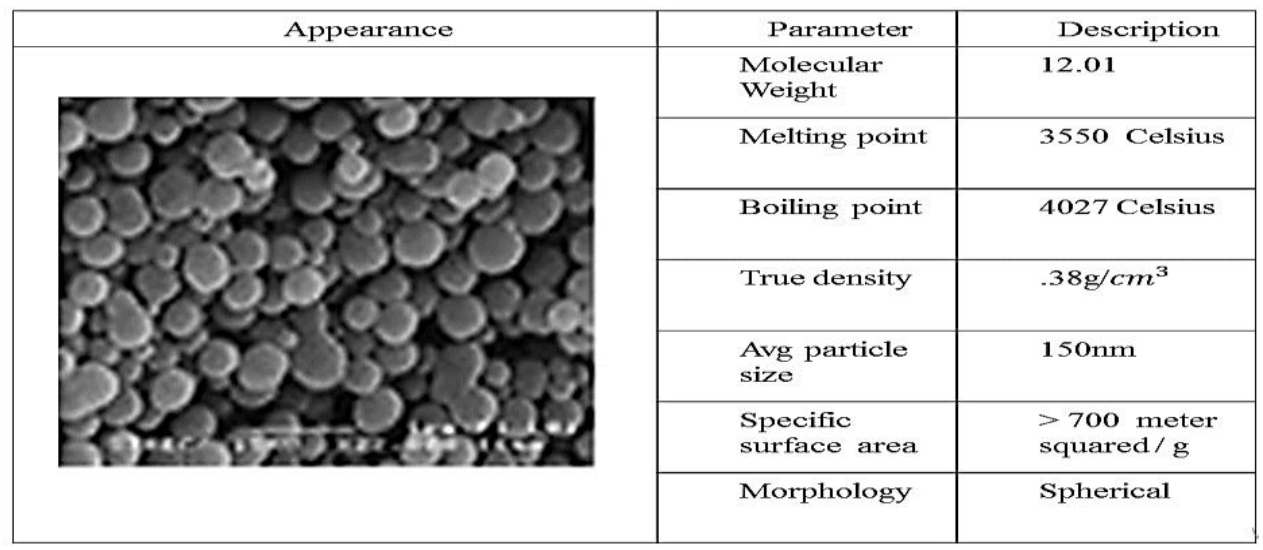

Table .1 Carbon Black Details

The titanium dioxide nanoparticle $\left(\mathrm{TiO}_{2}\right)$ are particle with the diameter that is very less than $100 \mathrm{~nm}$, these nanoparticles are transparent rather than white they have a strong absorption, of light as the band gap in the N-type 
Journal of Electronics and Informatics (2019)

Vol.01/ No. 02

Pages: 99-106

http://www.irojournals.com/iroei/

DOI: https://doi.org/10.36548/jei.2019.2.005

semiconductor for the conductivity and the valence band is wider compared to other substances. In the proposed method the carbon black nanoparticle is doped with the titanium dioxide nanoparticle to further enhance the photo catalytic activity. The micrograph of the titanium dioxide nanoparticle is presented below in the figure. 3

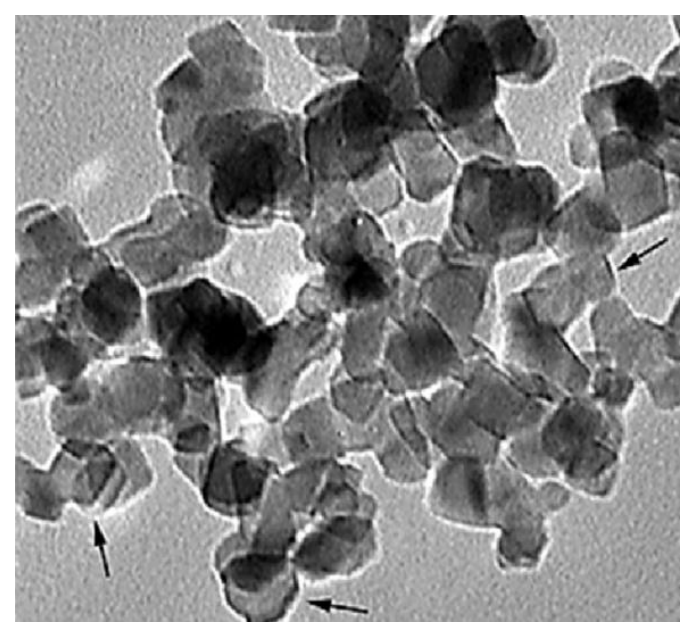

Figure.3 Micrograph of $\mathrm{TiO}_{2}$

The materials are combined, and they require a constant maintenance to ensure reliability in flow. The adding of small amount of carbon impurity to $\mathrm{TiO}_{2}$ in a regulated state is named as the $\mathrm{C}$-doping of titania. The added impurity enables the semiconductor to have a more number of conducting holes and electrons that are crucial for making the visible light active. Less than $1 \%$ of carbon black was doped with the titanium dioxide. The general chemical formula is denoted as the $\mathrm{TiO}_{2 x} C_{x}$ where the value of $\mathrm{x}$ depends on the preparation condition. The carbon doped in titanium improves its sensitivity to visible light absorption. The reactions of the titanium dioxide are represented in the equation (1), (2), (3) below.

$$
\begin{aligned}
& \mathrm{TiO}_{2}(\mathrm{~s})-\mathrm{TiO}_{2 \cdot x}(s)+x \mathrm{~V}_{\mathrm{o}}+x / 2 \mathrm{O}_{2}(g)\left(E_{\mathrm{f}_{-} \mathrm{Vo}_{\mathrm{o}}}=4.2 \mathrm{eV}\right) \\
& \mathrm{TiO}_{2} \mathrm{C}_{x}(s)-\mathrm{TiO}_{2 \cdot x} \mathrm{C}_{x}(s)+x \mathrm{~V}_{\mathrm{o}}+x 2 \mathrm{O}_{2}(g)\left(E_{\mathrm{f}_{-} \mathrm{vo}_{\mathrm{o}}}=3.4 \mathrm{eV}\right) \\
& \mathrm{TiO}_{2 \cdot x} \mathrm{C}_{x}(s)-\mathrm{TiO}_{2 \cdot 2 x} \mathrm{C}_{x}(s)+x \mathrm{~V}_{\mathrm{o}}+x 2 \mathrm{O}_{2}(g)\left(E_{\mathrm{f}_{-} \mathrm{V}_{\mathrm{o}}}=1.9 \mathrm{eV}\right)
\end{aligned}
$$

The carbon black and the titanium dioxide nanoparticles are placed near the junction of the active layer, to improve the blending properties, making the solution processable providing uniformity in printing and still improving the mobility and retaining the arrangement of the semiconductor materials even during the process of liquidation. 
Journal of Electronics and Informatics (2019)

Vol.01/ No. 02

Pages: 99-106

http://www.irojournals.com/iroei/

DOI: https://doi.org/10.36548/jei.2019.2.005

\section{RESULTS}

The OSC formed using the nanoparticle additives to improve its mobility and in turn increase power conversion efficiency as well as absorption of the sunlight. The figure.4 shows the modified structure of the conventional OSC that has included the $\mathrm{TiO}_{2}$ doped carbon black nanoparticle additive.

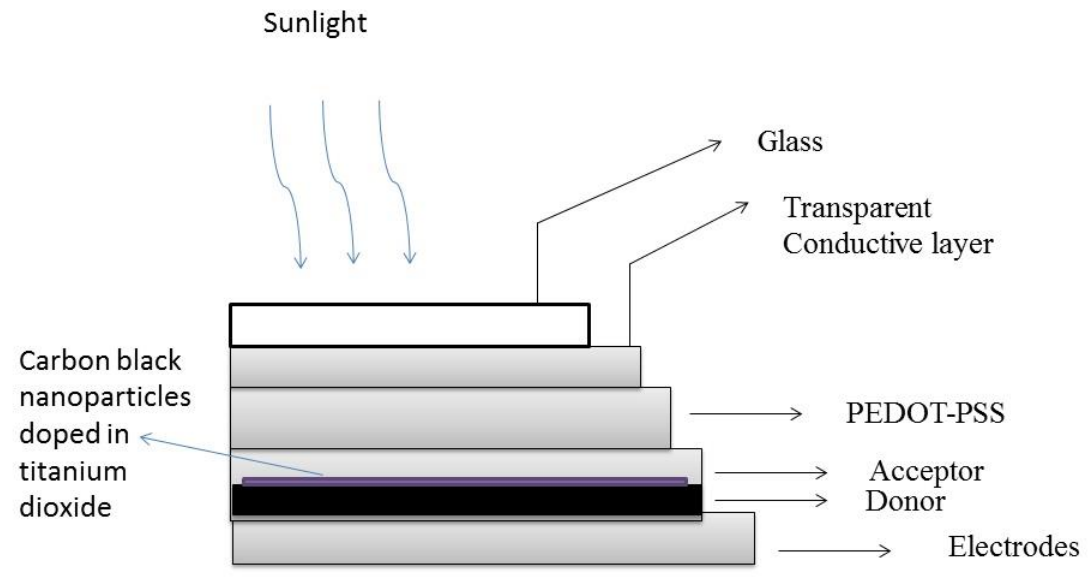

Figure.4 The Proposed Solar cell

The absorption rate of the proposed OSC is observed in the result attained from the TEM/SEM morphology; shows the absorption level of the OSC for the organic materials integrated the nanoparticles additives. The Results obtained shows that the absorption rate of the proposed -OSC is very much increased compared to the conventional.

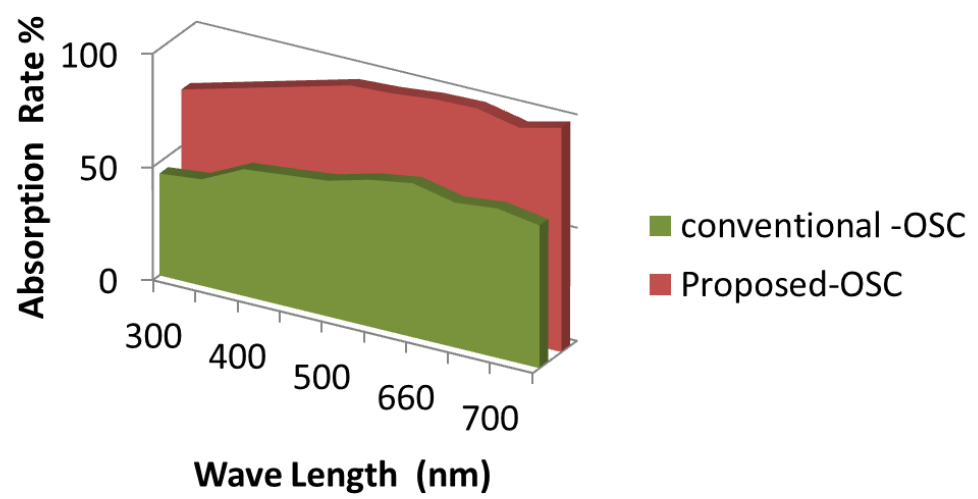

Figure.5 Absorption Rate 
Journal of Electronics and Informatics (2019)

Vol.01/ No. 02

Pages: 99-106

http://www.irojournals.com/iroei/

DOI: https://doi.org/10.36548/jei.2019.2.005

The figure. 6 below provides the improvement achieved in the power conversion efficiency of the ConventionalOSC, proposed-OSC, and the silicon solar cells, the results obtained shows that the proposed proves to have $2 \%$ higher PEC compared to the silicon based and the 3.5\% higher PEC than the conventional.

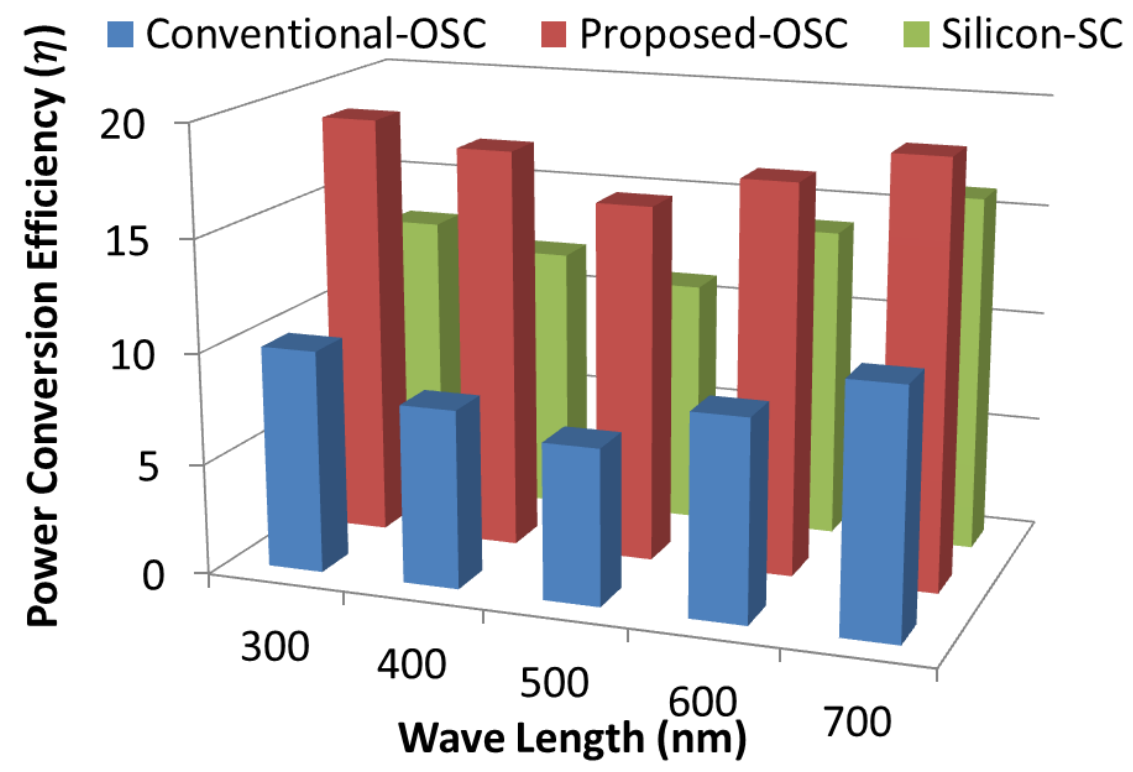

Fig.6 Power Conversion Efficiency

The figure.7 below shows the micrograph and the printed sheet of the proposed solar cell that is shows enriched performance in terms of power conversion efficiency, and absorption. The inclusive of the additives even minimizes the dimensions of the OSC.
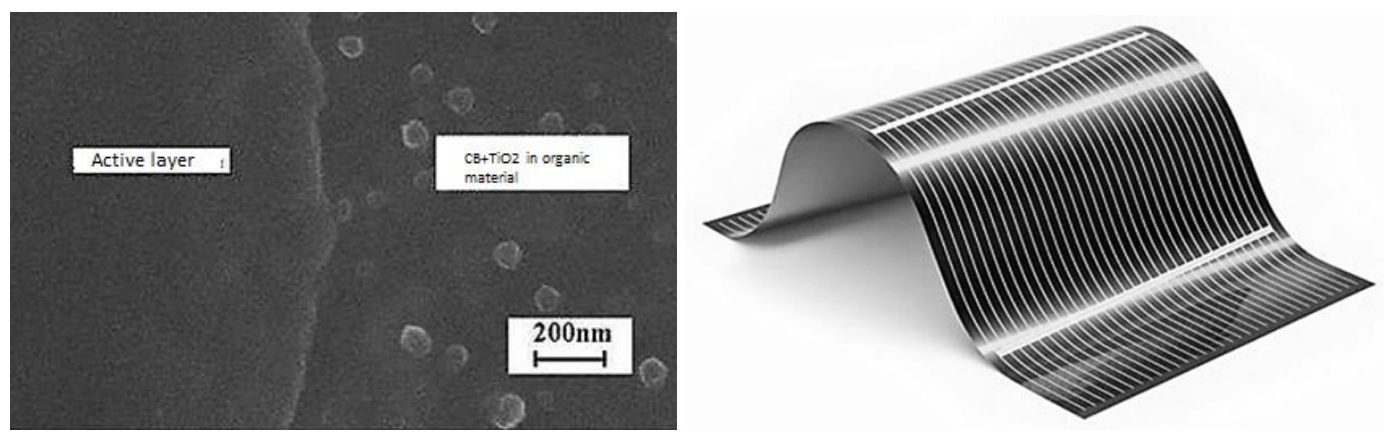

Fig.7 (left) Micrograph of OSC (right) Printed OSC 
Journal of Electronics and Informatics (2019)

Vol.01/ No. 02

Pages: 99-106

http://www.irojournals.com/iroei/

DOI: https://doi.org/10.36548/jei.2019.2.005

\section{CONCLUSION}

The innumerable advantages found in the organic- based electronic devices and their eco-friendly is attracting the manufactures to use the organic material for the making of the electronic components instead of using the silicon based devices, however as the field of the organic electronic are still in its early stage the realization of the application with the organic electronics challenging and less efficient. The proposed method in the paper tries to improve the power conversion efficiency in the solar cells that are based on the organic materials and achieves it using the carbon black and titanium dioxide nano particle as additive in the organic electronics by improving its solubility and uniformity in printing. This enhances the power conversion efficiency in the solar cells and the result observed proves the performance improvement achieved in terms of power conversion efficiency from $3.5 \%$ to $19 \%$.

\section{References}

[1] Forrest, Stephen R., and Mark E. Thompson. "Introduction: organic electronics and optoelectronics." Chemical Reviews 107, no. 4 (2007): 923-925.

[2] Kelley, Tommie W., Paul F. Baude, Chris Gerlach, David E. Ender, Dawn Muyres, Michael A. Haase, Dennis E. Vogel, and Steven D. Theiss. "Recent progress in organic electronics: Materials, devices, and processes." Chemistry of Materials 16, no. 23 (2004): 4413-4422.

[3] Palanivelu, K., Ji-Sun Im, and Young-Seak Lee. "Carbon doping of TiO 2 for visible light photo catalysis-a review." Carbon letters 8, no. 3 (2007): 214-224.

[4] Zhao, Xingang, and Xiaowei Zhan. "Electron transporting semiconducting polymers in organic electronics." Chemical Society Reviews 40, no. 7 (2011): 3728-3743.

[5] Shaw, Jane M., and Paul F. Seidler. "Organic electronics: introduction." IBM Journal of Research and Development 45, no. 1 (2001): 3-9.

[6] Perepichka, Igor F., and Dmitrii F. Perepichka, eds. Handbook of Thiophene-Based Materials: Applications in Organic Electronics and Photonics, 2 Volume Set. John Wiley \& Sons, 2009.

[7] Meyer, Jens, Sami Hamwi, Michael Kröger, Wolfgang Kowalsky, Thomas Riedl, and Antoine Kahn. "Transition metal oxides for organic electronics: energetics, device physics and applications." Advanced materials 24, no. 40 (2012): 5408-5427.

[8] Zhan, Xiaowei, Antonio Facchetti, Stephen Barlow, Tobin J. Marks, Mark A. Ratner, Michael R. Wasielewski, and Seth R. Marder. "Rylene and related diimides for organic electronics." Advanced Materials 23, no. 2 (2011): 268-284.

[9] Chen, Wangqiao, and Qichun Zhang. "Recent progress in non-fullerene small molecule acceptors in organic solar cells (OSCs)." Journal of Materials Chemistry C 5, no. 6 (2017): 1275-1302.

[10] Na, Seok-In, Byung-Kwan Yu, Seok-Soon Kim, Doojin Vak, Tae-Soo Kim, Jun-Seok Yeo, and DongYu Kim. "Fully spray-coated ITO-free organic solar cells for low-cost power generation." Solar Energy Materials and Solar Cells 94, no. 8 (2010): 1333-1337.

[11] https://pubs.rsc.org/en/content/articlehtml/2011/py/c1py00275a

[12] https://news.energysage.com/organic-solar-cells-what-you-need-to-know/

[13] https://news.energysage.com/organic-solar-cells-what-you-need-to-know/

[14] https://www.ncbi.nlm.nih.gov/pmc/articles/PMC5905289/

[15] Nirmal, D. "DESIGN AND EFFICIENCY ANALYSIS OF NANOCARBON INTERCONNECT STRUCTURES." Journal of Electronics 1, no. 01 (2019): 12-23.

[16] Bahn, Hyokyung. "EFFICIENT MANAGEMENT OF PROBE-BASED NANO STORAGE DEVICES." Journal of Electronics 1, no. 01 (2019): 1-11.

[17] Kumar, N. Mohan. "ENERGY AND POWER EFFICIENT SYSTEM ON CHIP WITH NANOSHEET FET." Journal of Electronics 1, no. 01 (2019): 52-59. 